\title{
MECHANICAL PROPERTIES AND METALLOGRAPHIC ANALYSIS OF PLASMA SPRAY APS - Ni5.5wt.\%AI5wt.\%Mo COATINGS
}

\section{Mihailo R. Mrdak}

Research and Development Center IMTEL Communications a.d., Belgrade, Republic of Serbia, e-mail: miki@insimtel.com, ORCID iD: (i)http://orcid.org/0000-0003-3983-1605

DOI: 10.5937/vojtehg67-17424; https://doi.org/10.5937/vojtehg67-17424

FIELD: Chemical technology

ARTICLE TYPE: Original scientific paper

ARTICLE LANGUAGE: English

\section{Summary:}

This paper presents the testing of the mechanical and microstructural characteristics of atmospheric plasma spray (APS) coatings of Ni5.5wt.\%Al5wt.\%Mo composite powder. The aim of this study was to optimize powder feed ( $\mathrm{g} / \mathrm{min})$ in order to deposit NiAIMo coating layers with optimum mechanical and structural characteristics to worn aviation parts made of Ni alloy exposed to a combination of corrosion and wear. The microhardness of the deposited layers was tested using $\mathrm{HV}_{0.3}$ and tensile bond strength was tested by tensile testing. The morphology of powder particles was examined on a SEM (scanning electron microscope). The NiAIMo coating microstructure was examined on an optical microscope (OM). Fracture morphology of the top layer was tested on an electronic scanning microscope (SEM). It was found that the control of powder feed can result in coatings with good bond strength.

Key words: atmospheric plasma spraying (APS), microstructure, Ni5.5wt.\%Al5wt.\%Mo, microhardness, bond strength.

\section{Introduction}

The development of surface engineering is mostly dynamic due to the fact that this discipline of science and technology is increasingly reliant on all key contemporary technological conditions such as: improving efficiency, saving materials, environmental protection, and so on.

ACKNOWLEDGEMENT: The author is thankful for the financial support from the Ministry of Education and Science of the Republic of Serbia (national project OI 174004, TR 34016). 
The surface engineering approach is even more useful since surfaces of metal components can be modified mechanically, chemically or physically. In the wide field of mechanical, chemical and metallurgical engineering, a series of problems is associated with wear and corrosion. Significant financial costs are caused by repair measures and downtime of plants. Many of these problems can be prevented by applying different coatings on highly loaded constructional parts. Technologies such as flame spraying and atmospheric plasma spraying (APS) are used where the application of coatings is economically justified to protect structural parts. Such produced coatings can provide new features to constructional parts (Mrdak, 2016). The plasma spraying method is one of the most flexible methods for thermal deposition of coatings and may be configured so that the jet of particles has a wide range of temperatures and speeds (Mrdak, 2018, pp.415-430). Fine powder particles are injected into plasma gas feed and they accelerate because of the transfer of velocity and temperature of ions onto powder particles. Under the substrate influence, particles deform plastically and bond to the substrate to form a coating. The process allows the deposition of a wide range of powders. Powder deposition speed is one of the most important parameters affecting the stress state of the coating which is directly related to the coating cohesion strength, microhardness and adhesion. Powder deposition speed can largely regulate a share of unmelted particles, pores and oxides in the coating. Powder deposition speed must be optimal in order to ensure complete melting of powder particles and reduce unmelted particles, pores and oxides in coating layers to the minimum. With powder deposition speed higher than the optimum speed, powder particles do not have enough time to melt completely, what leads to an increase in the share of unmelted particles and coarse pores in coating layers. Unmelted particles, together with pores, reduce cohesion and adhesion strength of the coating. A large proportion of unmelted particles and pores significantly reduces the protective effect of the coating in exploitation. Similar effects are caused by the feed of plasma gas, the intensity of electrical current and the distance of the substrate from the plasma gun (Mrdak, 2016). NiAIMo coating is one from a series of coatings based on $\mathrm{Ni}$ which, due to its characteristics, has found a wide application in the fields of mechanical, chemical and metallurgical engineering for protection and repair of functional parts. The coating is produced by applying powder Metco $447 \mathrm{NS}$ which can be deposited by all thermal spray processes. Metco $447 \mathrm{NS}$ (Ni5.5wt.\%Al5wt.\%Mo) is a composite of nickel-aluminummolybdenum powder intended for depositing coatings applying thermal 
spray processes. It is produced by mechanical deposition or by gas atomisation using an inert gas. A coated material consists of a core of nickel coated with aluminum and molybdenum. The morphology of produced particles is spherical with a nominal density of $3.5 \mathrm{~g} / \mathrm{cm}^{3}$. During thermal spraying, there is an exothermic reaction between nickel and aluminum (Al-Ni) and molybdenum and aluminum (Al-Mo), which increases the bond strength of the coating with the substrate and the cohesive strength between deposited particles. High values of mechanical properties of the NiAlMo coating were confirmed in the papers (Chen et al, 2015, pp.281). Plasma spraying of powders has produced perfect results of bonding between the substrate and the coating. Coatings are self-bonding with very good resistance to shock. The coating is applied at the operating temperature of $\leq 650{ }^{\circ} \mathrm{C}$. The NiAlMo coating is a good choice for the area which requires high toughness, corrosion resistance with moderate resistance to friction, erosion and scratch. The coating is applied to the areas such as: machine elements and bearings, wear rings, exhaust fans and collectors, diesel engines, fuel pump, valve seats, etc. (Oerlikon Metco, 2017). The microstructure of the triple alloy Ni-Al-Mo rich in $\mathrm{Ni}$ consists of small, coherent precipitates of the $\mathrm{Y}^{\prime}-\mathrm{Ni}_{3} \mathrm{Al}$ phases embedded in the base of the $\mathrm{Y}$ - phase rich in $\mathrm{Ni}$. The high mechanical strength of the Ni-based super alloy at elevated temperatures is mainly due to the presence of two phases consisting of a fine distribution of hard, coherent $\mathrm{Y}^{\prime}-\mathrm{Ni}_{3} \mathrm{Al}$ precipitates embedded in the base of the $\mathrm{y}$ - phase rich in $\mathrm{Ni}$. This heterogeneity of the composition and the presence of different crystallographic structures impede movements of dislocations, which leads to high strength and resistance to creep (Lin et al, 2018, pp.15501575). After the formation of the critical size of the nucleus, precipitates increase to reduce basis saturation, and in later stages, to reduce the total interface in the growth of large precipitates at the expense of smaller precipitates. The part of the Ni-Al-Mo system rich in Ni was intensively investigated. Parts of the three Ni-Al-Mo phase diagram have been published in the literature by (Miracle et al, 1984, pp.481-486). The isothermal cross-section of the three-phase diagram of Ni-Al-Mo at $1200{ }^{\circ} \mathrm{C}$ near the corner rich in $\mathrm{Ni}$ is presented in Figure 1. At this temperature, the two phase region of $\mathrm{y}^{-\mathrm{Ni}}+\mathrm{Y}^{\prime}-\mathrm{Ni}_{3} \mathrm{Al}$ is separated from the region of the $Y$ - phase, with the region of the $Y^{\prime \prime}$ - phase and the threephase region which includes $\gamma, \gamma^{\prime}$ and $\delta$ - phases, where the last phase is $\delta$-NiMo intermetallic compound. One of the main reasons for alloying the dual Ni-Al system with Mo arises from a possibility of changing the mismatch between the $\mathrm{y}$ lattice and the $\mathrm{Y}^{\prime}$ phase. Another important 
parameter is a possibility of adjusting the content of $\mathrm{Al}$ in relation to $\mathrm{Ni}$ (Conley et al, 1989, pp.1251-1263). Ni-Al-Mo composite is produced by the method of unidirectional solidification of the alloy eutectic composition. Solidification of $\mathrm{Ni}$-Al-Mo alloy produces the $\mathrm{Y}$-Ni phase as the basis and coherent $\mathrm{Y}^{\prime}-\mathrm{Ni}_{3} \mathrm{Al}$ precipitates embedded in the $\mathrm{y}$ basis, as well as the phase of the a-Mo lamellar structure (Ishak \& Takagi, 2012, pp.416-420), (Rico et al, 2010, pp.531-550).

The main objective of this study was to homogenise Ni 5.5wt.\%Al5wt.\%Mo coating layers and apply them on the worn aircraft parts of $\mathrm{Ni}$ alloys exposed to a combination of corrosion and wear. The two groups of samples were made with two powder feed values of 30 $\mathrm{g} / \mathrm{min}$ and $60 \mathrm{~g} / \mathrm{min}$. We analyzed the mechanical properties and the microstructure of the coating layers on the basis of which the best-quality coating was chosen.

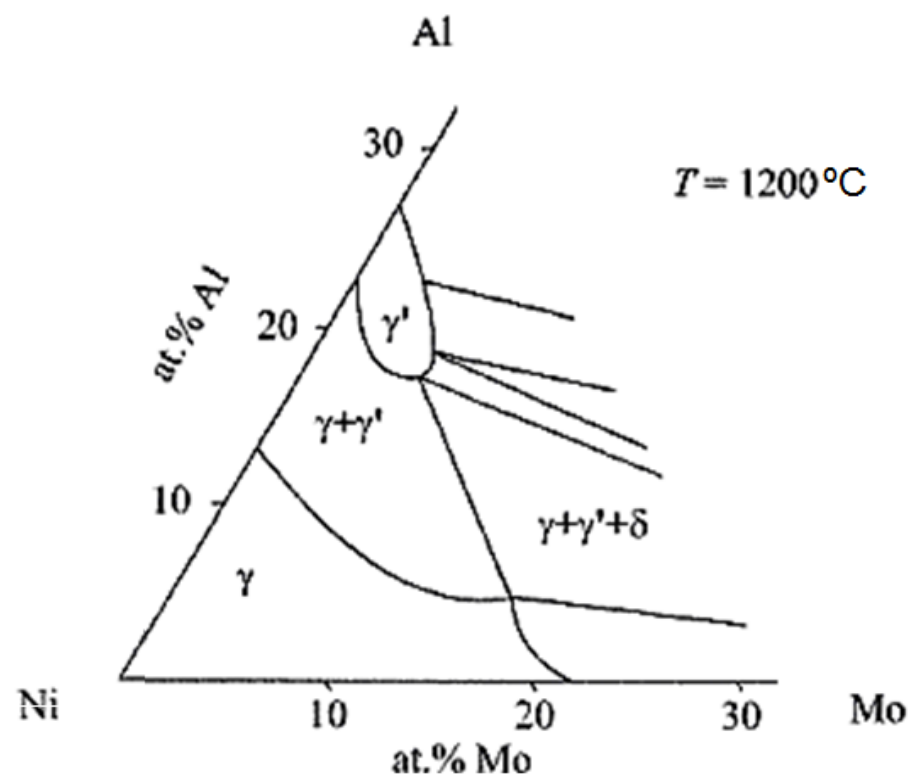

Figure 1 - Part of the Ni-rich Ni-Al-Mo phase diagram at $1200^{\circ} \mathrm{C}$ (Miracle et al, 1984 , pp.481-486)

Puc. 1 - Часть фразовой диаграммы Ni-Al- Mo, обогащенного Ni при $1200^{\circ} \mathrm{C}$ (Miracle et al, 1984, pp.481-486)

Слика 1 - Део фразног дијаграма Ni-Al- Mo богатог Ni на $1200{ }^{\circ} \mathrm{C}$ (Miracle et al, 1984, pp.481-486) 


\section{Materials and experimental details}

Powder of the Oerlikon Metco company labelled Metco 447 NS was used for the experiment. Ni5.5wt.\%Al5wt.\%Mo composite powder is produced by mechanical deposition or by gas atomisation using an inert gas (Oerlikon Metco, 2017). Powder particles are spherical which enables smooth flow of powder in the plasma jet. The range of granulation of powder particles used in the experiment was from 45 to 90 $\mu \mathrm{m}$. Figure 2 shows the SEM scanning electron photomicrographs of the morphology of Ni5.5wt.\%Al5wt.\%Mo powder particles.

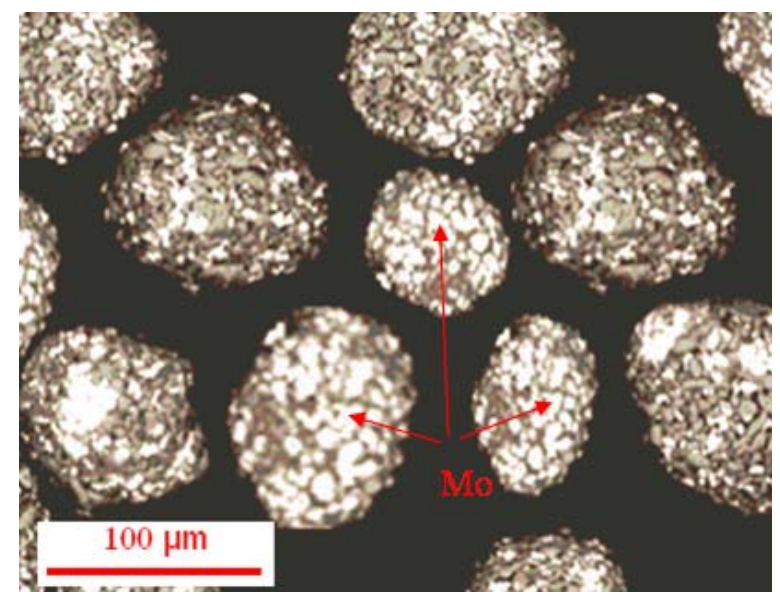

Figure 2 - (SEM) Scanning electron micrography of Ni5,5wt.\%Al 5wt.\% Mo powder particles

Puc. 2 - (СЭМ) Сканирующая электронная микроскопия частиц порошка Ni5,5вес.\%Al 5вес.\% Мо

Слика 2 - (CEM) Скенинг електронска микрографрија честица праха Ni5,5теж.\%Al Бтеж.\% Мо

For the deposition of Ni5.5wt.\%Al5wt.\%Mo composite powder, the atmospheric plasma spraying system (APS) of the Plasmadyne company was used as well as the SG-100 plasma gun consisting of the K 1083-129 cathode, the A 2084-145 anode and the GI 2083-113 gas injector. Ar was used as arc gas in a combination with $\mathrm{He}$ and the power supply was $40 \mathrm{~kW}$. Powder feed $(\mathrm{g} / \mathrm{min})$ was the basic parameter for the preparation of coatings. The experiment involved two powder feed values, $30 \mathrm{~g} / \mathrm{min}$ and $60 \mathrm{~g} / \mathrm{min}$. Powder feed is one of the important parameters affecting the quality of the coating, which is directly related to cohesion strength, microhardness and adhesion of the coating. With 
large powder feed, particles do not have enough time to melt fully, which leads to an increased share of partially molten particles and pores in the coating layers. Partially molten powder particles, together with pores, reduce the cohesive and adhesion strength of the coating. With reduced powder feed, particles are completely melted and, under the substrate influence, deform plastically in a more appropriate way, bonding to the substrate with a smaller proportion of pores. The detailed values of the plasma spray parameters are shown in Table 1. Prior to powder deposition, the substrate surface is roughed with corundum $\mathrm{Al}_{2} \mathrm{O}_{3}$ with a particle size of $0.7-1.5 \mathrm{~mm}$. The coatings were deposited with a thickness of up to $0.30 \mathrm{~mm}$.

Table 1 - Plasma spray parameters

Таблица 1 - Параметры плазменного напыления Табела 1 - Плазма спреј параметри

\begin{tabular}{|l|l|}
\hline Deposition parameters & Values \\
\hline Plasma current, I (A) & 800 \\
\hline Plasma Voltage, U (V) & 32 \\
\hline $\begin{array}{l}\text { Primary plasma gas } \\
\text { feedrate } \mathrm{Ar},(\mathrm{I} / \mathrm{min})\end{array}$ & 47 \\
\hline $\begin{array}{l}\text { Secondary plasma gas } \\
\text { feedrate He, (I/min) }\end{array}$ & 32 \\
\hline $\begin{array}{l}\text { Carrier gas } \\
\text { feedrate Ar, }(\mathrm{I} / \mathrm{min})\end{array}$ & 7 \\
\hline Powder feed rate, $(\mathrm{g} / \mathrm{min})$ & $30 / 60$ \\
\hline Stand-off distance, $(\mathrm{mm})$ & 80 \\
\hline
\end{tabular}

The testing of the structural and mechanical characteristics of the coatings was done in accordance with the Pratt \& Whitney standard (Pratt \& Whitney, 2002). The bases on which Ni5.5wt.\%Al5wt.\%Mo coatings were deposited for microhardness testing and evaluation of microstructure in the deposited state were made of thermally unprocessed C.4171 (X15Cr13 EN10027) steel with the dimensions of $70 \times 20 \times 1.5 \mathrm{~mm}$ (Pratt \& Whitney, 2002). The bases for testing bond strength were also made of thermally unprocessed Č.4171 (X15Cr13EN10027) steel wih the dimensions of $\varnothing 25 \times 50 \mathrm{~mm}$ (Pratt \& Whitney, 2002). Microhardness testing of Ni5.5wt.\%Al5wt.\%Mo coating layers was done using the method $\mathrm{HV}_{0.3}$ and bond strength was tested by tensile testing. The microhardness measurement was performed in the direction along the lamellae. Five readings were obtained, in the middle and at the ends of the samples, which were then averaged. Bond 
strength testing was done at room temperature with a tensile speed of $1 \mathrm{~cm} / 60 \mathrm{~s}$. For each group of samples, three specimens were tested. The morphology of Ni5.5wt.\%Al5wt.\%Mo powder particles was examined by scanning electron microscopy (SEM). The microstructure of Ni5.5 wt.\%Al5wt.\% Mo coating layers in the deposited state was tested on an optical microscope (OM). The fracture morphology of the best Ni5.5 wt.\%Al5wt.\%Mo coating layers in the deposited state was examined on the SEM.

\section{Results and discussion}

The values of the microhardness and the bond strength of the deposited Ni5.5wt.\%Al5wt.\%Mo coating, depending on powder feed, are shown in Figures 3 and 4.

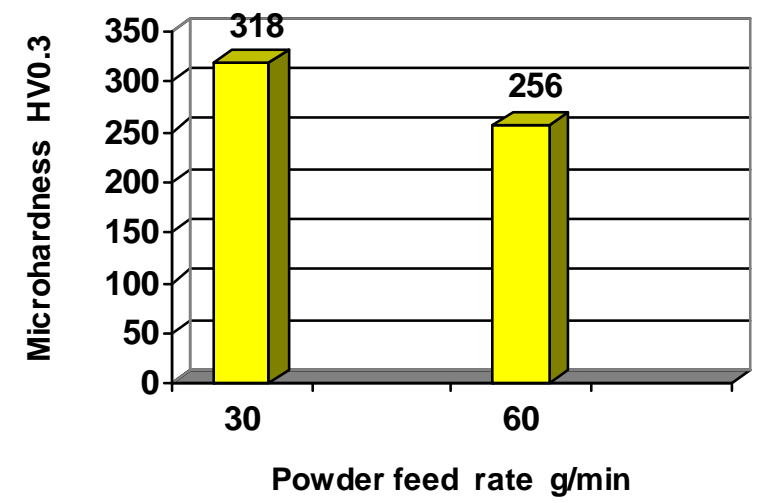

Figure 3 - Microhardness of Ni5,5wt.\%Al5wt.\%Mo layers Puс. 3 - Микротвердость Ni5,5вес.\%Al5вес.\%Мо слоев Слика 3 - Микротврдоћа Ni5,5теж.\%АI5теж.\%Мо слојева

The microhardness values of the layers directly depended on the powder feed. The bond microhardness and strength values of Ni5.5wt.\%Al5wt.\%Mo deposited layers were significantly affected by powder feed. The layers deposited with a lower powder feed of $30 \mathrm{~g} / \mathrm{min}$ had a higher microhardness value of $318 \mathrm{HV}_{0.3}$. These layers showed the best microstructure with the densest packing of molten particles and with a lower proportion of pores, which was confirmed by metallographic examination. The layers with the largest share of pores which were deposited with the largest powder feed of $60 \mathrm{~g} / \mathrm{min}$ have a microhardness 
value lower than $256 \mathrm{HV}_{0.3}$. The microhardness values of these layers were significantly lower. Larger powder feed resulted in less pronounced melting of powder particles and less packaging on each other accompanied by a higher share of interlamellar pores.

Tensile bond strength was directly related to the feed of Ni5.5wt.\%Al 5wt.\%Mo powder. The highest value of the bond strength of $56 \mathrm{MPa}$ was found in the layers with a higher microhardness value and the smallest proportion of pores. These layers were deposited at a powder feed rate of $30 \mathrm{~g} / \mathrm{min}$. The lowest bond strength value of $32 \mathrm{MPa}$ was found in the layers deposited with a powder feed rate of $60 \mathrm{~g} / \mathrm{min}$ which had lower microhardness. The failure mechanism for both deposited coatings was adhesion at the interface between the substrate and the Ni5.5 wt.\%Al5wt.\%Mo coating.

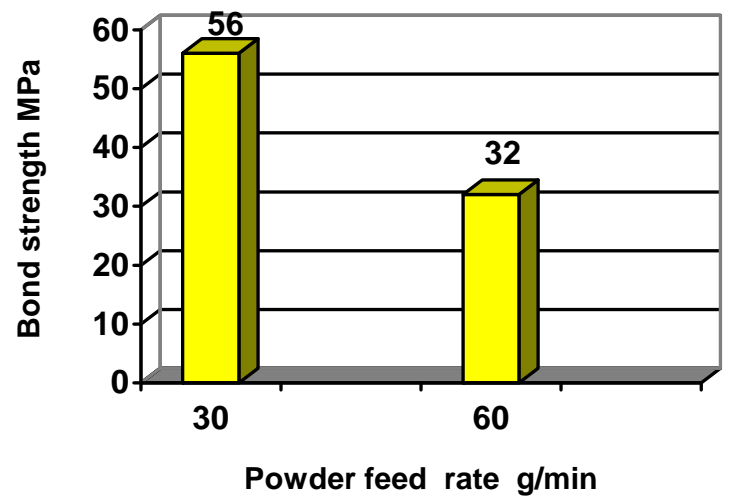

Figure 4 - Bond strength of Ni 5,5wt.\%Al5 wt.\%Mo layers Puc. 4 - Прочность сцепления Ni5,5вес.\%Al5вес.\%Мо слоев Слика 4 - Чврстоћа споја Ni5,5теж.\%Al5mеж.\%Мо слојева

Figures 5 and 6 show the (OM) photomicrographs of the Ni5.5wt.\%Al5wt.\%Mo layers deposited with a powder feed rate of 30 $\mathrm{g} / \mathrm{min}$ and $60 \mathrm{~g} / \mathrm{min}$. The microstructural analysis of the NiAlMo coatings showed that the layers were deposited on the substrate continuously without interruption and without the presence of micro-cracks and macrocracks at the interface. At the interface between the coating and the substrate, contamination provoked by roughening was not observed (Fig. 6). The well-prepared substrate surface enabled obtaining good bond strength values. The micrographs clearly show different proportions of pores in the deposited layers. The smallest proportion of pores was 
present in the layers of the NiAlMo coatings deposited with a powder feed of $30 \mathrm{~g} / \mathrm{min}$. In these layers, the total proportion of pores was $2 \%$. In the coating layers deposited with a powder feed rate of $60 \mathrm{~g} / \mathrm{min}$, the proportion of pores was $5 \%$. The proportion of pores in the NiAIMo coating layers correlated with the proportion of unmelted particles. The microstructure of the inner layers of the coating deposited at a powder feed rate of $30 \mathrm{~g} / \mathrm{min}$. is lamellar (Fig. 5).

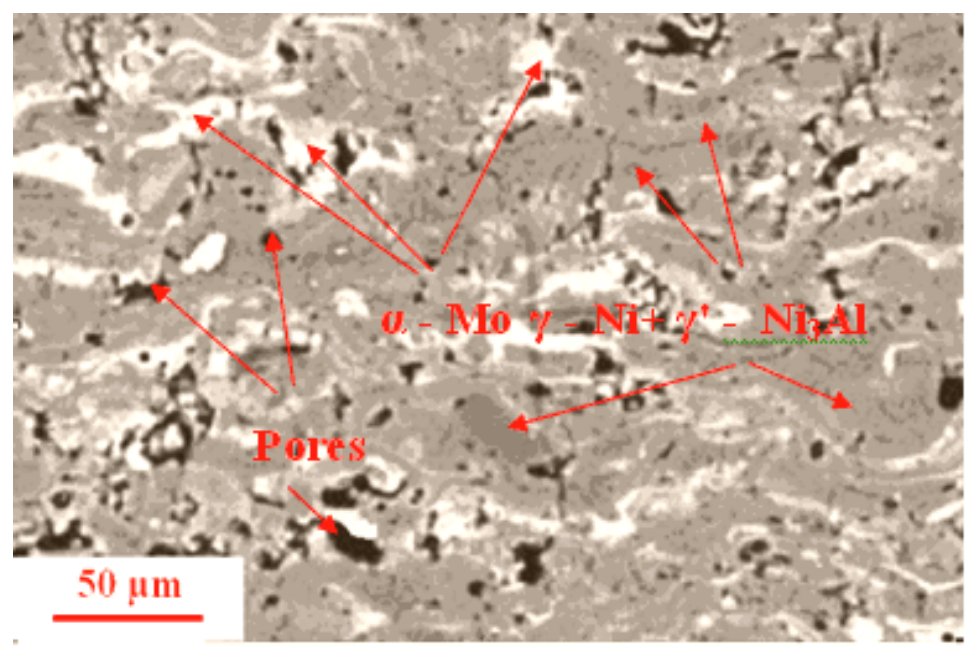

Figure $5-(\mathrm{OM})$ Microstructure of the Ni5,5wt.\%Al5 wt.\%Mo coating deposited with a powder feed rate of $30 \mathrm{~g} / \mathrm{min}$

Puc. 5 - (ОМ) Микроструктура Ni5,5вес.\%АІ5вес.\%Мо покрытия, нанесенного порошковым напылением 30 г/мин

Слика 5 - (ОМ) Микроструктура Ni5,5теж.\%A/5теж.\%Мо превлаке депоноване протоком праха $30 \mathrm{~g} / \mathrm{min}$

The coating base consists of a solid solution of $\mathrm{y}-\mathrm{Ni}$ rich in nickel in which the precipitates are $\mathrm{Y}^{\prime}-\mathrm{Ni}_{3} \mathrm{Al}$ phases. In the microstructure of the coating, the lamellae of a lighter phase of molybdenum a-Mo are clearly observed (Ishak \& Takagi, 2012, pp.416-420), (Rico et al, 2010, pp.531$550)$. In the lamellar base of the solid solution of $\mathrm{Y}-\mathrm{Ni}$ and the intermetallic phases of $\mathrm{Y}^{\prime}-\mathrm{Ni}_{3} \mathrm{Al}$, there are clearly visible dark fields representing inter-lamellar pores which are much finer in relation to the micro pores present in the coating layers deposited with a feed rate of $60 \mathrm{~g} / \mathrm{min}$. The coating layers do not contain unmelted powder particles and precipitates which may occur as a result of collision of molten drops with the substrate (Fig. 5). 


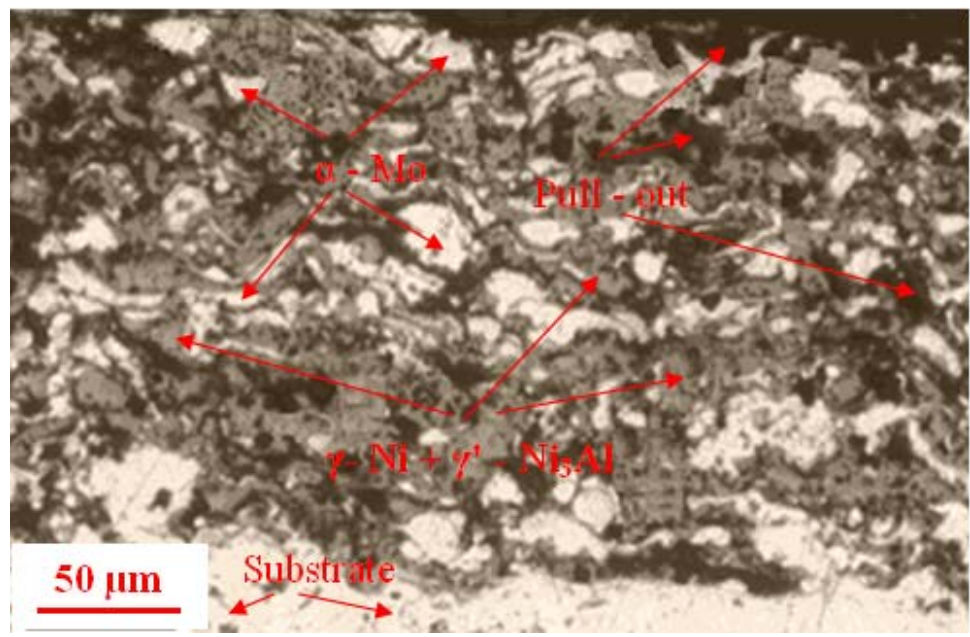

Figure 6 - (OM) Microstructure of the Ni5,5wt.\%Al5 wt.\%Mo coating deposited with a powder feed rate of $60 \mathrm{~g} / \mathrm{min}$

Puc. 6 - (ОМ) Микроструктура Ni5,5вес.\%AІ5вес.\%Мо покрытия, нанесенного порошковым напылением 60 г/мин

Слика 6 - (ОМ) Микроструктура Ni5,5теж.\%AI5теж.\%Мо превлаке депоноване протоком праха $60 \mathrm{~g} / \mathrm{min}$

In the microstructure of the NiAlMo coatings deposited with a powder feed of $60 \mathrm{~g} / \mathrm{min}$ (Fig. 6), it is possible to see a significant proportion of incompletely melted powder particles which are less plastically deformed in a collision with the substrate surface. The morphology of the deposited particles is more spherical; therefore, the structure is not fully lamellar. Between partially molten globules there are black pores which are quite rough and irregular. Due to a large amount of powder feed into the plasma jet and its low melting point, a properly layered lamellar structure of the deposit could not be formed. Black fields in the microstructure (pull-out) represent the locations of extracted particles nearly spherical in shape, which result from pulling out incompletely melted powder particles from the base during sample preparation. Solidification of Ni-Al-Mo composite powder particles resulted in the microstructure as in Fig. 5 consisting of $\mathrm{Y}$-Ni phases rich in $\mathrm{Ni}$ as the basis and coherent $\mathrm{Y}^{\prime}-\mathrm{Ni}_{3} \mathrm{Al}$ precipitates embedded in the $\mathrm{Y}$ basis. The a-Mo molybdenum phases of more globular than lamellar morphology are clearly ooserved in the microstructure (Ishak \& Takagi, 2012, pp.416-420), (Rico et al, 2010, pp.531-550). Micro-cracks are not 
observed through the deposited layers. The best microstructure is found in the layers deposited at a feed rate of $30 \mathrm{~g} / \mathrm{min}$.

Figure 7 shows the fracture photomicrographs of the NiAlMo coating layers deposited with a powder feed of $30 \mathrm{~g} / \mathrm{min}$. The fracture surfaces of the coatings were examined on the SEM in order to analyze their morphology. The fracture of the NiAlMo coating surface shows a continuous structure with layered deposited melted particles. The analysis of the sample showed that the coating was decomposed and highly fractured, as it can be seen in the figure, especially in the area above the fracture toughness zone. The fracture occurred between the lamellae of the deposited particles. During fracture, cracks commonly propagate along lamelar interfaces where the bond is weaker than through lamellae which requires much higher strain.

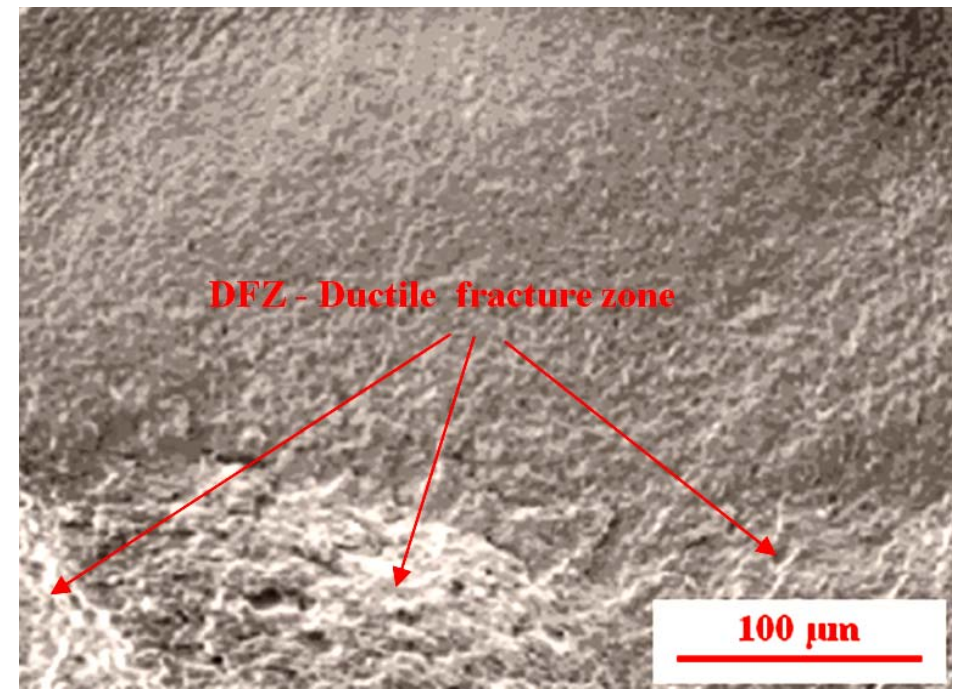

Figure 7 - (SEM) fracture morphologies of NiAIMo coatings deposited with a powder feed rate of $30 \mathrm{~g} / \mathrm{min}$

Puc. 7 - (СЭМ) Морфология трещин в NiAIMо покрытии, нанесенном порошковым напылением 30 г/мин

Слика 7 - (SEM) Морфологије лома NiAIMо превлаке депоноване протоком праха $30 \mathrm{~g} / \mathrm{min}$

Figure 7, therefore, presents the interlamellar fracture mode. The fracture toughness zone is clearly visible in the lower part of the sample. 


\section{Conclusion}

In this paper, APS - atmospheric plasma spraying was used for depositing Ni-Al-Mo powder coatings with a feed rate of 30 and $60 \mathrm{~g} / \mathrm{min}$. The mechanical properties have been analyzed as well as the microstructures of the coatings in the deposited state, and the following conclusions were drawn.

The mechanical properties of microhardness and bond strength as well as the microstructure of Ni-Al-Mo coatings were directly dependent on powder feed. The layers deposited with a lower powder feed of $30 \mathrm{~g} / \mathrm{min}$ had a higher microhardness value, $318 \mathrm{HV}_{0.3}$. These layers were more homogeneous and denser with a share pore of $2 \%$, which resulted in a higher value of bond strength.

The structure of the Ni-Al-Mo coating layers deposited with a lower powder feed of $30 \mathrm{~g} / \mathrm{min}$ is lamellar consisting of a solid solution of $\mathrm{Y}-\mathrm{Ni}$ rich in nickel in which there are precipitates of the $\mathrm{Y}^{\prime}-\mathrm{Ni}_{3} \mathrm{Al}$ phase and the molybdenum a-Mo phase lamellae.

The fracture of the Ni-Al-Mo coating surface deposited with a lower powder feed of $30 \mathrm{~g} / \mathrm{min}$ shows compact microstructure with layers of deposited melted particles. The crack propagates easier along border surfaces of deposited molten particles where the bond is weaker than through the $\mathrm{Y}-\mathrm{Ni}+\mathrm{y}^{\prime}-\mathrm{Ni}_{3} \mathrm{Al}$ grain boundaries in each molten particle. During fracture, the mode of fracture was favorable interlamellar with a present fracture toughness zone.

The obtained results showed that powder feed in the process of deposition affects the mechanical properties and the microstructure of the coating layers. The examination of the coatings have confirmed that the best layers are those deposited with a powder feed of $30 \mathrm{~g} / \mathrm{min}$.

The application of Ni-Al-Mo coatings in repair of aircraft parts based on Ni-alloys exposed to a combination of corrosion and wear significantly improves the efficiency and reliability of parts in service and significantly reduces costs of repair.

\section{References}

Chen, J., Zhou, H., Zhao, X., Chen, J., An, Y., \& Yan, F. 2015. Erratum to: Microstructural Characterization and Tribological Behavior of HVOF Sprayed NiMoAl Coating from 20 to $800{ }^{\circ} \mathrm{C}$. Journal of Thermal Spray Technology, 24(3), pp.281-281. Available at: https://doi.org/10.1007/s11666-014-0193-z.

Conley, J., Fine, M., \& Weertman, J. 1989. Effect of lattice disregistry variation on the late stage phase transformation behavior of precipitates in Ni-AlMo alloys. Acta Metallurgica, 37(4), pp.1251-1263. Available at: https://doi.org/10.1016/0001-6160(89)90119-3. 
Ishak, M., \& Takagi, H. 2012. The characteristics of unidirectional solidified Ni-Al-Mo alloys. Materialwissenschaft und Werkstofftechnik, 43(5), pp.416-420. Available at: https://doi.org/10.1002/mawe.201200975.

Lin, B., Huang, M., Zhao, L., Roy, A., Silberschmidt, V., Barnard, N., Whittaker, M., \& McColvin, G. 2018. 3D DDD modelling of dislocationprecipitate interaction in a nickel-based single crystal superalloy under cyclic deformation. Philosophical Magazine, 98(17), pp.1550-1575. Available at: https://doi.org/10.1080/14786435.2018.1447159.

Miracle, D.B., Lark, K.A., Srinivasan, V., \& Lipsitt, H.A. 1984. Nickelaluminum-molybdenum phase equilibria. Metallurgical Transactions A, 15(3), pp.481-486. Available at: https://doi.org/10.1007/bf02644971.

Mrdak, M. 2016. Plazma sprej procesi $i$ svojstva zaštitnih prevlaka.Beograd: IHIS Techno experts d.o.o. (in Serbian).

Mrdak, M. 2018. Transfer of heat and speed of plasma particles to powder particles in the plasma spray process at atmospheric pressure. Vojnotehnički glasnik/Military Technical Courier, 66(2), pp.415-430. Available at: https://doi.org/10.5937/vojtehg66-12942.

-Oerlikon Metco. 2017. Material Product Data Sheet, Nickel - Aluminum Molybdenum Thermal Spray Powders. DSMTS-0111.0. [online] Available at: file://C:/Users/Intel/Downloads/DSMTS-0111.5 NiAIMo_Powders.pdf.

Accessed: 10.05.2018.

-Pratt \& Whitney. 2002. Turbojet Engine. Standard Practices Manual.East Hartford,USA: Pratt \& Whitney. (PN 582005).

Rico, A., Rodríguez, J., \& Otero, E. 2010. High Temperature Oxidation Behaviour of Nanostructured Alumina-Titania APS Coatings. Oxidation of Metals, 73(5-6), pp.531-550. Available at: https://doi.org/10.1007/s11085-0109191-9.

МЕХАНИЧЕСКИЕ СВОЙСТВА И МЕТАЛЛОГРАФИЧЕСКИЙ

АНАЛИЗ Ni5.5вес.\%АІ5вес.\%МО ПОКРЫТИЯ, НАНЕСЕННОГО ВОЗДУШНО-ПЛАЗМЕННЫМ НАПЫЛЕНИЕМ

Михаило Р. Мрдак

Центр исследований и развития А.О. «ИМТЕЛ коммуникации»,

г. Белград, Республика Сербия

РУБРИКА ГРНТИ: 61.13.21 Химические процессы

ВИД СТАТЬИ: оригинальная научная статья

ЯЗЫК СТАТЬИ: английский

Резюме:

В данной статье представлены результаты испытаний механических и микроструктурных характеристик покрытия из композитного порошка Ni5,5вес.\%Al5вес.\%Мо, нанесенного воздушно-плазменным напылением (ВПН). Целью исследования являлась оптимизация потока порошковой струи (г/мин) при нанесении слоев NiAIMo покрытия, обладающего оптимальными 
механическими и структурными характеристиками, на части самолетов, которые подвергаются сочетанию коррозии и износа. Данные части изготовлены из сплавов Ни. Микротвердость нанесенных слоев, испытывалась методом HVO.3, а прочность на разрыв сцепления - методом растяжения. Морфрология поверхности частиц порошка исследовалась с помощью СЭМ сканирующего электронного микроскопа. Микроструктура НиАлМ покрытия была исследована с помощью оптического микроскопа (ОМ). Морфология трещин, образовавшихся в лучших слоях, исследовалась с помощью сканирующего электронного микроскопа (СЭМ). Испытания показали, что при контролируемом потоке порошковой струи слои нанесенного покрытия обладают высокой прочностью сцепления.

Ключевые слова: воздушно-плазменное напыление (ВПН), микроструктура, Ni5,5вес.\%Al5вес.\%Мо, микротвердость, прочность сцепления.

МЕХАНИЧКА СВОЈСТВА И МЕТАЛОГРАФСКА АНАЛИЗА ПЛАЗМА CПРЕЈ АПС - Ni5.5теж.\%АІ5Теж.\%Мо ПРЕВЛАКЕ

Михаило Р. Мрдак

Истраживачки и развојни центар ИМТЕЛ -КОМУНИКАЦИЈЕ а.Д., Београд, Република Србија

ОБЛАСТ: хемијске технологије

ВРСТА ЧЛАНКА: оригинал научни рад

ЈЕЗИК ЧЛАНКА: енглески

Сажетак:

У овом раду представљена су испитивања механичких и микроструктурних карактеристика атмосферски плазма спреј (АПС) превлака од композитног праха Ni5,5теж.\% Al5mеж.\%Мо. Циљ истраживања био је да се оптимизира проток праха (г/мин) како би се депоновали слојеви NiAIMo превлаке оптималних механичких и структурних карактеристика који ће се применити на похабаним ваздухопловним деловима од легура $\mathrm{Hu}$ изложени комбинацији корозије и хабања. Микротврдоће депонованих слојева урађене су методом $H_{0.3}$ и затезне чврстоће споја методом испитивања на затезање. Морфологија површине честица праха испитана је на СЕМ-у (скенинг-електронском микроскопу). Микроструктура НиАлМо превлака испитана је на оптичком микроскопу (ОМ), а морфологија лома најбољих слојева на СЕМ-у. Утврђено је да се контролом протока праха могу произвести слојеви превлаке са добром чврстоћом споја.

Кључне речи: атмосфрерски плазма спреј (АПС), микроструктура, Ni5,5теж.\%Al5теж.\%Мо, микротврдоћа, чврстоћа споја. 
Paper received on / Дата получения работы / Датум пријема чланка: 11.05.2018. Manuscript corrections submitted on / Дата получения исправленной версии работы / Датум достављања исправки рукописа: 04.04.2019.

Paper accepted for publishing on / Дата окончательного согласования работы / Датум коначног прихватања чланка за објављивање: 06.04.2019.

(C) 2019 The Author. Published by Vojnotehnički glasnik / Military Technical Courier (www.vtg.mod.gov.rs, втг.мо.упр.срб). This article is an open access article distributed under the terms and conditions of the Creative Commons Attribution license (http://creativecommons.org/licenses/by/3.0/rs/).

(c) 2019 Автор. Опубликовано в «Военно-технический вестник / Vojnotehnički glasnik / Military Technical Courier» (www.vtg.mod.gov.rs, втг.мо.упр.срб). Данная статья в открытом доступе и распространяется в соответствии с лицензией «Creative Commons» (http://creativecommons.org/licenses/by/3.0/rs/).

(c) 2019 Аутор. Објавио Војнотехнички гласник / Vojnotehnički glasnik / Military Technical Courier (www.vtg.mod.gov.rs, втг.мо.упр.срб). Ово је чланак отвореног приступа и дистрибуира се у складу са Creative Commons licencom (http://creativecommons.org/licenses/by/3.0/rs/).

(c) (i) 